\title{
Community Empowerment Management in Realizing Healthy School
}

\author{
Wihardiyani $^{1)}$, Wahyudi $^{2)}$, M. Chiar ${ }^{3)}$ \\ ${ }^{1)}$ Universitas Tanjungpura, Pontianak, Indonesia \\ E-mail:wharyani.spd@gmail.com \\ ${ }^{2)}$ Universitas Tanjungpura, Pontianak, Indonesia \\ E-mail:wyudi_fkip@yahoo.com \\ ${ }^{3)}$ Universitas Tanjungpura, Pontianak, Indonesia \\ E-mail: chiarfkip@gmail.com
}

\begin{abstract}
Schools and communities have a very close relationship in realizing school or education goals. But the reality in implementing school activities is sometimes more often separating between schools and surrounding communities. This study aims to describe the planning, implementation, and evaluation of community empowerment in realizing healthy schools at Public Elementary School (SDN) No. 6 Siantan, Siantan District, Mempawah Regency. The approach used in this study is a qualitative approach with a type of case study research. The data analysis model used is Model Miles and Huberman. Based on the research that has been done, the following results are obtained: 1) The process of planning community empowerment in referring to healthy schools has gone well; 2) The implementation of community empowerment has gone well which can be seen through cooperation in both activities between institutions (SDN No. 6 Siantan) and the community; and 3) Evaluation of community empowerment activities in realizing healthy schools carried out at the end of each activity by the principal of the sub-district education office UPT and the school committee.
\end{abstract}

Keywords: Empowerment; Community; Management; Healthy School

\section{INTRODUCTION}

Community empowerment is an alternative concept of development that is loved today. Conceptually empowerment becomes an ideal, logical, rational and even systematic concept. Community empowerment is a process so that everyone or a group of people participate in various controllers, and influence events that affect their living conditions. Empowerment here is more pressing on the ability of people or groups of people to participate, meaning that the community is not only the object of development projects, but they also participate in the development.

In empowering the process, approach is more likely to implement development that humanizes humans. In this view, the involvement of the community in development is more directed at the form of participation, not in the form of mobilization. Community participation in program formulation makes the community not only as program consumers, but also as producers because they have participated in the process of making and formulating it, so that people feel that they have the program and have responsibility for its success and have more motivation for participation in the next stages (Soetomo, 2006).
In order to cultivate healthy life in children, it should be instilled from an early age through basic education. The activity is one of the school programs that is integrated with School Health Business activities. School Health Business (UKS/M) is one program that must be realized and implemented in order to improve the quality of education. The UKS program is important for improving health status. Based on Law No. 23 of 1999 regulating the realization of the healthy living capacity of every resident, one way is by fostering healthy schools. Then reinforced by Law No. 36 of 2009 concerning health article 76 states that "School health is held to improve the healthy living abilities of students in a healthy environment so that students can learn, grow, and develop harmoniously and be as high as human resources. quality. Health in schools is a shared responsibility between students, teachers, the community and the government. As we all know, the School Health Business (UKS) in various regions is still not as expected, and has not even received full support even though health care efforts for students are a link to improving the health of the population. 
In the world of education, the existence of schools and communities cannot be separated, because in educating the life of the nation it is not only the responsibility of the government and parents but also the responsibility of the community. The relationship between the school and the community is essentially a tool that plays a role in fostering and developing the personal growth of students in school. Schools and communities have a very close relationship in realizing school or education goals. But the reality in the implementation of school activities is sometimes more often separates between the school and the surrounding community. The activities carried out tend to activities that do not involve the community around the school to play an active role, this could occur due to lack of attention and community support for schools so far. The community thinks that we provide sufficient funds for the rest of the school that regulates the implementation. This is inversely proportional to SDN 6 Siantan which will implement a healthy school program, the school invites parents, community and government agencies involved to participate in the implementation of the school program.

Based on the facts in the field, where the people around SDN Number 6 Siantan strongly support the school program to be implemented by the school. The community support is realized by having an active role in helping the school in preparing all the facilities needed to support the implementation of a healthy school program. In its implementation, not only were the people involved but there were also members of the TNI and Polri, community social institutions including PKK members who worked together to support these activities. Therefore, the success of the school in implementing the school program cannot be separated from the efforts and hard work carried out by the school and can not be separated from community participation, this is proof that the importance of community empowerment in supporting the success of SDN Number 6 Siantan in the Subdistrict of Siantan, Mempawah (first) Provision Health School Competition Program in West Kalimantan in 2017. This is impossible to achieve without the participation of parents and the community around the school. This is inseparable from the role of the principal who is able to implement the management function well, starting from planning, implementation, and evaluation. Based on this background the question arises "How is Community Empowerment in Realizing a Healthy School.

\section{RESEARCH METHOD}

This study uses a qualitative approach with the research method used which is qualitative descriptive. According to Nazir in Andi Prastowo (2011: 186) explained that the descriptive method is a method used to examine the status of a group of humans, an object, a set of conditions, a system of thought, or a class of events in the present. This type of research is a case study because, in accordance with the understanding of case studies, researchers will examine a case about Community Empowerment in Realizing a Healthy School Competition Program in SDN Number 6,
Siantan District, Mempawah District. Data were analyzed using the Miles and Huberman model.

\section{RESULT AND DISCUSSION}

\section{A. Results}

In empowering the community in realizing a healthy school program implementing management functions of education which consist of planning, organizing, implementing and supervising. The four administrative management functions are the basis for the implementation of community empowerment in realizing a healthy school program at SDN No 6 Siantan located in Jalan Parit Bilal, Siantan District, Mempawah Regency, West Kalimantan Province. But in the implementation of community empowerment management in realizing a healthy school program at SDN No 6 Siantan located in Jalan Parit Bilal, Siantan Subdistrict, Mempawah Regency, West Kalimantan Province, only applying three principles of education management, namely, planning, implementation, and evaluation.

For data collection on community empowerment in realizing a healthy school program at SDN No 6 Siantan, it is located in Jalan Parit Bilal, Siantan District, Mempawah Regency. On June 4, 2018, the researcher came to SDN No 6 Siantan to meet with the principal then explained the intent and purpose of the arrival of the researcher, the researcher was accepted by the principal to be happy to conduct research in the institution he supervised, then the researcher submitted a research permit from the Study Program Chair Management of Educational Administration to the head of SDN No 6 Siantan, Siantan District, Mempawah Regency. Lapse one day the researcher precisely on June 52018 the researcher carried out the research to SDN No 6 Siantan the Subdistrict of Siantan in the Mempawah Regency immediately carried out the interview with the principal, the Educator Staff, the school committee, the parents of the student, and the related community shop that was determined to become the informant. The author also observed and requested that the documents owned by SDN No 6 Siantan be located on Jalan Parit Bilal, Jungkat Village, Siantan District, Mempawah Regency.

In order to obtain accurate data, of course, researchers must collect as much information as possible from the determined informants, namely the principal, Educators, School Committees, Representatives of Parents of Students, Community Leaders.

Field observations by taking photos of locations, photographs of community activities in improving facilities to support healthy schools, are carried out every time after the interview. On the same occasion also requested documents needed so that in one day get as information needed in research. The research utilizes each free time to type transcripts of interviews, analyze them and revisit the interviewee data, to ensure that the intent of the answers given is indeed like the one in the interview transcript. it turns out there is an interview section. After reviewing the transcript of the interview, 
there were parts of the answers he added, especially when answering planning questions, because they were not mentioned in full at the interview.

From the results of interviews, observations and documentation studies and documentation studies the researchers obtained the following picture:

1. Community Empowerment Planning in realizing healthy schools

Community empowerment in realizing healthy schools must begin with planning. Forms of planning in the field of education that are commonly owned by schools include (1) Vision and Mission, (2) Medium Term Work Plan (RKJM), (3) School Activity Budget Plan/RAKS and RAPBS. The results of interviews, observations and documentation in community empowerment planning in referring to healthy schools obtained the following data:

a. Interview result

Data obtained from interviews with school principals, vice principals, 5 (five) teachers, parents and school committees, and the community regarding community empowerment management in realizing healthy schools in SDN Number 6 Siantan are like summaries of interview results as follows:

1) Vision and Mission

Community empowerment in

Public Elementary School Number 6

Siantan is felt to be very supportive of achieving the school's Vision and Mission. If you see the vision of the school, you don't really see the relationship, but the school mission clearly illustrates the close relationship that community empowerment is one of the efforts to realize the school's mission in achieving the vision of SDN Number 6 Siantan.

The interview results obtained information that the Vision and mission of SDN Number 6 Siantan were set at the school meeting which was attended by principals, teacher boards, school committees, parents of students and community leaders. Therefore, to realize the vision and mission, it is not just school responsibility, but indirectly a little more is the responsibility of parents and the community.

2) Goals, Benefits, and targets for empowerment

The purpose is a statement about the desired condition in which the organization or company intends to make it happen and as a statement about the situation in the future where the organization as a collectivity tries to create it. In other words, the goal is the realization of a specific mission that can be carried out in the short term, while the aim of community empowerment is to invite the community to support school work programs by participating both directly and indirectly as a form of responsibility for implementing the vision and mutually agreed school mission.

The results of the interview obtained information that the purpose of community empowerment in realizing healthy schools is to establish cooperative relations between schools and communities in supporting all healthy school programs, in addition to the purpose of community empowerment in realizing healthy schools to provide benefits for the school with community participation in activities carried out in school it is very helpful and supports the success of the school in preparing a healthy school program so that the target for implementing a healthy school program can be realized.

3) Healthy school program

Public Elementary School Number 6 Siantan has a work program in the form of an annual program and semester work program. One of the school work programs is a healthy school work program. The interview results obtained information that a healthy school program is an activity to increase understanding, and awareness and shape the behavior of school residents to live healthy lives, both at school and at home. SDN Number 6 Siantan has implemented a healthy school program that has been implemented since the school was established, only at that time it was only limited to cleaning the classroom and schoolyard, but only received serious attention from 2013 until now, so that healthy school program activities can run well, to $\mathrm{We}$ form the management committee for a healthy school area with a decree. Underlying our implementation of a healthy school program is based on Law Number 23 of 1999 regulating the realization of the healthy living capacity of every resident, one of the ways is by fostering healthy schools. Strengthened by Law Number 36 of 2009 concerning health article 76.

Which includes healthy school programs at SDN Number 6 Siantan namely:

(a) Gradually cleaning the school environment. 
Carry out cleaning classes and school environments every day to avoid rubbish and dust.

(b) Planting Plants in the School Environment

Planting activities are carried out in the school environment by utilizing existing vacant land. The land is used to provide students with knowledge and experience. students are invited to go directly to the land to plant sweet potatoes and peanuts. Seen students were very enthusiastic about planting the plants. It is hoped that with these activities, students can use the surrounding environment well to maintain environmental sustainability.

(c) School Health Business

The legal basis for implementing UKS/ $\mathrm{M}$ refers to the Joint Regulation (SKB) between the Minister of Education and Culture Number 6/X/PB/2014, Minister of Health Number 73 of 2014, Minister of Religion of Republic of Indonesia Number 41 of 2014, Minister of Home Affairs Number 81 of 2014 concerning the Development and Development of UKS (School/Madrasah Health Unit). The activities carried out to improve the health of school-age children on each path, type, and level of education. School Health Unit (UKS) aims to improve the quality of education and student achievement by improving clean and healthy living behaviors and creating a healthy educational environment, thereby enabling students to develop harmonious growth and development. The School Health Unit (UKS) is one of the platforms for the implementation of the Character Education Strengthening (PPK) program that covers clean living, protecting the environment and health. UKS is an important component in implementing UKS implementing healthy schools with the availability of UKS in schools so children can be taught how to cope with children experiencing health problems, then what steps should be taken by UKS officers. And it is hoped that this UKS can act as a small health center in the school environment.

(d) Washing hands with clean water and soap

One indicator of healthy schools in schools is washing hands with running water and using soap. It has long been known by the public that hand washing is a way of preventing and protecting yourself against disease-causing germs. Wash hands with soap when before and after meals. After BAK and BAB and before and after doing the work will be very effective in maintaining the health of the body and prevent the spread of disease through viruses and bacteria that are not visible to the eye attached to the hand.

(e) Snacks in Healthy canteens

Some schools have applied the criteria for managers of healthy canteens, managers of healthy canteens must meet the requirements given by the school to the managers of the school canteen. There are several requirements that must be adhered to by the school canteen manager, namely as follows, namely

(1) Not providing brightly colored food or drinks strikingly.

(2) Not providing hard or charred food.

(3) Train students to always check packaging labels before buying.

(4) Have a hand washing place.

In addition to the five criteria above, there are still other characteristics of a healthy canteen that must be considered. These features include canteen facilities and infrastructure, as well as the healthy lifestyle that the managers carry out. Namely clean water sources, storage areas, processing sites, serving and dining rooms, sanitation facilities, work equipment, and waste disposal sites.

(f) Dispose of Trash in its place.

Waste is a source of disease, many diseases are caused by garbage. Examples of diarrhea and vomiting are diarrhea and shortness of breath or other diseases related to the effects caused by the stench of garbage. However, getting used to throwing trash in its place is not an easy thing. Getting used to throwing out trash is very difficult as well as getting children to learn.

Habit is one of the things that must be done continuously. So that habits become someone's needs when they get used to it. Habits can be raised with the guidance of parents or teachers because children's habits cannot be raised by themselves must be with 
guidance. With guidance, habits can be raised by one's awareness. Give good guidance to children, of course, the good habits of children will appear and vice versa

To familiarize children to dispose of trash in its place in the school environment, a teacher carefully provides guidance and education on the introduction of hazardous waste, children are introduced to until organic and inorganic, and hazardous waste. So that with knowledge, children are more aware of their habit of littering. At school in order to familiarize children to dispose of garbage in its place other than with guidance, there must be a landfill. This can make it easier for children to throw garbage in its place. Bins must be available at every point or place. The more rubbish bins, the school environment will be clean, comfortable and protected from all diseases.

(g) Exercise regularly at school

Sport is a series of regular and planned movements to choose motion (to maintain life) and improve movement ability (improve quality of life). Sport is a form of physical activity that is complex and structured, which extends over and over again and is aimed at improving physical fitness.

(h) Using healthy slides in school

Latrines are places that are used for human waste. Latrines in Indonesia are also known as latrines/toilets. Cleanliness of latrines is absolutely necessary to prevent transmission of bacteria and viruses that cause disease among school residents who use them. The use of latrines together makes the rate of transmission of the disease increase, so that the cleanliness of latrines that are maintained can reduce the rate of transmission of bacteria and viruses that cause disease.

Basic sanitation toilets that must be owned by every school. The importance of removing clean water in clean latrines is to avoid various types of diseases that arise due to poor sanitation. Therefore latrines must follow the standards of making healthy bridges which must be located at least 10 meters from water sources and have air drainage channels so as not to pollute the environment. So that a toilet is needed that meets the requirements of a healthy toilet.

Terms of healthy latrines include:

(1) Not contaminating water reservoirs

(2) There is no contact between humans and feces

(3) The results of fecal waste do not cause odor

(4) Enough lighting

(5) Enough ventilation

(6) Sufficient water

(7) Quite extensive

(8) Waterproof floor

(9) Construction of latrines is well made so that it is safe for its users

(10) Cleaning tools are available

To support a healthy school program, latrines must be available that meet health requirements and have cleaning equipment. clean and odorless latrines besides showing cleanliness also reduce the number of bacteria and germs that cause disease.

(i) Eradicate mosquito larvae at school The uniforms used by elementary school students (SD) are still short-sleeved, also the pants and skirts of the students, without realizing it is a big risk to schoolchildren bitten by mosquitoes at school.

Mosquito larvae are the forerunner of mosquitoes, if not immediately eradicated, the results obtained are many mosquitoes in the environment. Mosquitoes are one of the carriers of bacteria and viruses that cause disease, so the presence of mosquitoes must be eradicated. larva eradication aims to reduce the growth rate of mosquitoes so as to avoid diseases caused by mosquito bites.

The way to eradicate mosquito larvae is known as $3 \mathrm{M}$, namely:

(1) Drain and brush the walls of water reservoirs such as bathtubs / toilets, drums, shelter of air conditioning, refrigerators, etc. once a week.

(2) Closing meetings of water shelters such as water barrels / jars, holy water sites, etc.

(3) Burying or removing used items that can hold rainwater such as used cans, used tires, used bottles, etc.

Besides 3M, mosquito control methods can also be done by:

(1) Use mosquito nets when sleeping

(2) Avoid the habit of hanging clothes in the room 
(3) Using drugs that can prevent mosquito bites

(4) Seek adequate lighting and ventilation

(5) Repair damaged channels and gutters

(6) Sprinkle larvae powder in a place that is difficult to drain

(7) Maintain larvae fish in ponds and water reservoirs

To support School activities, schools should have a water reservoir that meets health requirements, and school residents must use a mosquito larvae that is free of water.

(j) No Smoking in School

Cigarettes are cylindrical objects from paper and have a length between 70 to $120 \mathrm{~mm}$ with a diameter of about $10 \mathrm{~mm}$ containing tobacco leaves that have been roughly cut. Cigarettes are burned at one end and allowed to burn so that the smoke can be sucked by the mouth through the other end. Smoking is the activity of sucking cigarette smoke into the body and blowing it into the air, and smoking is like a factory.

In one cigarette smoked will be released around 4000 dangerous chemicals, the most dangerous ones are nicotine, tar, and carbon monoxide. Nicotine causes addiction and damages the heart and blood flow, tar causes lung damage and cancer, while carbon monoxide causes reduced ability of blood to oxygen, so cells will die. Therefore smoking is prohibited in the school environment because cigarette smoke is very dangerous for children who breathe it. People who become passive smokers are more dangerous than active smokers because the ones smoked are carbon monoxide which is beneficial for health, especially for children.

(k) Weighing Weight and Measuring Height Every 6 (Six) Months

Consuming healthy foods is a must, especially for school-age children who are in the stage of height growth and weight development. Weight is the size of the body in terms of the weight that is weighed in a state of minimal clothing without any equipment. Height is the size of the body in the height that is measured in a state of minimal clothing without any equipment. The growth and development of children at school age are very rapid, so it is necessary to record the growth and development of the body regularly.

By knowing a person's weight and height, it can be estimated the level of health or nutrition. Weight and height are recommended to measure the state of nutrition because:

(1) Easy to see

(2) Provide an overview of the nutritional state at this time and if done at least every 6 months for children periodically will be able to provide a good picture of the growth of children

(3) The accuracy of measurements is not influenced by measuring skills

(4) Measuring instruments are easily obtained

Some things that affect body weight and height include food and drink. Within a day the human body needs complete nutrition such as carbohydrates, fats, proteins, vitamins, and minerals. To support school activities, schools should have a schedule for weighing and measuring height and schools must have the means to weigh weight and measure height.

(1) Provision of Infrastructure

No matter how good the activity program is prepared but in the implementation it is not supported by adequate facilities and infrastructure, it is impossible to run optimally, as well as greeting the implementation of the school program needs to be supported by the availability of adequate infrastructure so that it can support the activities to be carried out. Therefore, it is necessary to provide or renovate existing facilities, among others:

(1) Supply of 15 liters of clean water/ person/day

(2) Provision of a place to wash your hands with running water and their accessories

(3) The proportion of toilet is 1 toilet for 40 students and 1 toilet for 25 female students

(4) Waste Disposal Facilities

(5) Liquid Waste Management

(6) Waste disposal facilities

(7) Solid Waste Management

(8) Means of Socialization and Education 
(9) Health Education Facilities

(10) Health Service Facilities

(11) Healthy School Environment Development Facilities, etc.

4) Socialization of the Healthy School Program.

Socialization is the process of providing information, adapting, adjusting, introducing and translating the main program activities of the organization so that organizational activities can be carried out in accordance with the planning and rules given.

The socialization was carried out in the hope of building perceptions of the organization's vision and mission, which was marked by the level of program implementation in activities that were able to involve all elements of the organization in order to accelerate program implementation and overall organizational goals.

From the interviews, information was obtained that the socialization of the healthy school program had been carried out by SDN No. 6 Siantan, the socialization of school programs including healthy school programs we conducted at holding meetings with parents and the community, then at the time of the ceremony and through the school announcement board, we did not carry out socialization using posters, billboards, and banners because there were no funds. Dissemination of school programs and health programs did not involve the community directly but worked with the school committee given the busyness of the community in carrying out daily activities that cause people not to have time to disseminate healthy school programs actively.

5) Plans, Budgets, and Costs

Budget planning here talks about how to get money and how to allocate (allocate) what should be so that the use of funds is as far as possible on the right target or objective. Budget planning was prepared to facilitate implementation and find out whether the exact calculation or not in community empowerment activities in realizing a healthy school principal had made a healthy school plan.

Based on the interview results, information was obtained that community empowerment activities in realizing a healthy school 6 Siantan has made a budget and cost plan before this activity is carried out, budgeting plans initially conducted meetings with the teacher board and school committee to determine the budget that will be used in the activities of a healthy school program, there are funds that can not be funded by schools, then we hold meetings with parents and the community to discuss funding that cannot be funded by the school to ask for opinions from the community from the parents and the community to find a solution.

6) Schedule

Scheduling is a design activity in the form of allocating resources both machines and labor to run a set of tasks according to the process in a certain period of time". The method used to agree on the time and place for the implementation of activities by taking into account the input from the program activities can be carried out as planned. Activities can run well, of course, there needs to be a schedule of activities so that activities carried out in accordance with the time set in the plan made.

The results of the interview obtained information that the activities of community empowerment in realizing a healthy school, made a schedule of activities but not permanent in nature tentative this adjusts to the activities, parents of school committees and the community and related stakeholders.

2. Implementation of Community Empowerment in realizing healthy schools

a. Coordinating the implementation of community empowerment in realizing a healthy School.

A joint agreement process that binds various activities or elements that are different in such a way, so that on the one side all activities or elements are directed towards achieving a predetermined goal and on the other hand the success of one activity does not damage the success of the other activities. coordination is carried out to create and maintain organizational effectiveness as high as possible through synchronization, harmonization, togetherness, and balance between various activities dependent on an organization. In addition, it prevents conflicts and creates the highest efficiency in each of the different interdependent activities through agreements that bind all parties concerned.

The results of the interviews obtained information that community empowerment activities in realizing our healthy schools coordinated before the activities were carried out, this was done so that there was a common perception in the implementation in accordance 
with the plans that had been prepared. We coordinated with the school committee, the head of the education office and even the head of the sub-district office to seek support for the implementation of the school program, after we coordinated then we were invited to hold a coordination meeting involving parents of students, the community, related institutions, and the Muspika district. The goal so that they know about the program will be carried out and ask for support from the participants so that the program can run according to the plan and ask the community to support and can play an active role and the implementation of a healthy school program. We coordinated with the sub-district Muspika, the Head of the Sub-District Education and Culture Office, the school committee, the village head, the hamlet head, the community, and the community's parents. The coordination was carried out by visiting one of the agencies and conducting meetings at the school.

b. Division of tasks for community empowerment in realizing a healthy School.

The division of tasks in an institution needs to be carried out according to the needs of the organization so that there is no overlap in the implementation of work so as to cause a buildup of work at one point and vacancy at another point. the division of tasks within the organization also aims to simplify the work of the members of the organization so that the work is quickly completed. In community empowerment activities in the realization of healthy schools, there is also a division of tasks carried out by the Principal.

The results of the interview obtained information that community empowerment in embodying our healthy school is to divide the outside affairs of the school into my duty as headmaster and be accompanied by one of the teachers, then for matters within the school appoint teachers who already have a part.

c. Parental involvement in realizing healthy schools.

Parental involvement is not new in the educational environment and has played a real role. It is very clear and undeniable that parental involvement is very appropriate and the positive impact is very broad. Parents depend on how well the design, planning, and application of each type of parent involvement is expected.

The interview results obtained information that community empowerment in realizing healthy schools parents of students very actively play activity in schools, they help in the form of funds or material even they also help in the form of preparing facilities to support the implementation of a healthy school program.

d. Administrative activities for community empowerment in creating healthy schools.

Administrative activities are very important in the organization. The importance of administration in organizations because administration is an activity carried out through cooperation in an organization based on a predetermined plan to achieve the goal. Administrative activities are very important in the organization. The importance of administration in organizations because administration is an activity carried out through cooperation in an organization based on a predetermined plan to achieve the goal. Likewise, in community empowerment activities in realizing healthy schools neither can it be released from administrative activities. Because from the start of planning, implementation and evaluation is part of the administration.

The interview results obtained information that in community empowerment activities in realizing healthy schools cannot be separated from administrative activities, namely activities related to making attendance lists and minutes of meetings.

3. Evaluation of community empowerment in realizing healthy schools

As we know that supervision and evaluation is a part that determines the success or failure of a program, even evaluation is saving information that will be used as a reference for subsequent policymaking. This supervision and evaluation aim to ensure that the tasks provided have been carried out in accordance with the plan or not, then, whether it shows good performance so that the planned targets can be realized in accordance with the plan.

In observing the author of this one management function, very little effort has been made relating to community participation to end without saving any information that can be used as material for the study of subsequent policymaking. Based on the results of the interview obtained information that the implementation of community empowerment in realizing healthy schools is as follows:

a. Evaluation of community empowerment activities in realizing healthy schools

To find out whether a planned goal is achieved or not, an evaluation is needed. From the evaluation, we can find out the extent to which the planned goal is achieved, in addition to knowing the obstacles faced in achieving the objectives, then find a solution to overcome them. 
From the interview results obtained information that the evaluation of community empowerment activities in realizing healthy schools by looking at the progress of the success of the planned activities / objectives achieved and recording any activities that have not been completed or work that has not been done is then conducted a meeting to discuss the problem. the principal always monitors every activity carried out, sometimes the Head of the UPT of the District Education and Culture Office also monitors the ongoing activities, if there is a job that is not perfect or has not been done then a meeting is held to find out what is being faced to find a solution.

b. Evaluation of the objectives of community empowerment activities in realizing healthy schools has been achieved.

Objectives are targets that the institution intends to achieve in carrying out its activities as an indicator of achieving success.

Based on the interview results, information was obtained that community empowerment in embodying a healthy school was evaluated by looking at the progress of the success of the planned activities / objectives achieved and noting that any activities that had not been completed or work that had not been done were then held to discuss the problem. Before the evaluation, the principal always monitors every activity carried out, sometimes the Head of the UPT of the District Education and Culture Office also once monitors the activities carried out if there are jobs that are not perfect or have not been carried out so that the solution is found.

c. Engagement of related agencies

Puskesmas is an institution that is directly involved in a healthy school program, the role of the puskesmas is very important in providing guidance and technical guidance about health in the school environment.

The interview results obtained information that in community empowerment activities in realizing healthy schools involving puskesmas the role of puskesmas in realizing healthy schools they gave consideration and input after seeing the work results related to improving school facilities.

\section{B. Discussion}

Based on the findings of the study, the researcher discussed and presented the results of research on the implementation of a healthy school program at SDN No. 6 Siantan starts from planning, implementation, and evaluation. This data is obtained from interviews and documentation studies. The results can be described as follows:
1. Stage of Planning

Planning is a process of determining what you want to achieve in the future and determining the steps needed to achieve it. In line with that according to Maise and Volwahsen (1998: 2) planning as a pivot circle that repeats from a series of logical steps. in the opinion of Siswanto (2015: 420), planning is an integrative activity that seeks to maximize the effectiveness of the entire organization as a system, in accordance with the objectives to be achieved. This means that planning is a process of determining what you want to achieve in the future and determine the stages needed to achieve it. The planning process is a process whereby all things are needed when implementing activities and aiming for a smooth and successful program or activity to be carried out.

In planning also think about determining what will be done, how to do it, who is implementing it, and when the activity is carried out. Thus the planning of the implementation of a healthy school program is a series of thought activities in the process of implementing a healthy school program, from a work program, forming work time, socializing, preparing a budget and cost plan, and arranging a schedule or schedule.

This is in line with the opinion of Saefudin Saud (2005: 17) that planning can be interpreted as a drafting process as a decision that will be implemented in the future to achieve a predetermined goal. What is planned are things that must be done with regard to the implementation of a healthy school program. Opinions about the importance of planning were also expressed by Anderson and Bowman (in Sustisna 1989: 192) Planning is the process of preparing a set of decisions for future actions. This definition suggests that planning leads to the making of decisions. Making decisions is an important part of planning.

This is reinforced by Sagala (2002: 46) states that planning includes activities to determine what you want to say, how to achieve it, how long, some people needed, how much money is needed. This opinion is in line with the opinion of Handoko (2003: 79) that planning is basically through four stages, namely: (1) setting goals, (2) formulating current conditions, (3) identifying all facilities and constraints.

Planning for a healthy school program is carried out at the beginning of the year based on the principal's work program. Before planning a healthy school activity program, an analysis of program requirements is carried out by: (1) analyzing a healthy school program (2) identifying the types of program activities to be implemented (3) identifying potential parents, educators and communities (4) designing the program activities needed and (5) determine the program to be implemented. So by 
referring to the existing theory, it is stated that the process of planning a healthy school program activity has gone through the right stage or mechanism.

The findings in the field in developing empowerment planning together with the planning of school programs including the health school program were carried out at the beginning of the year. The preparation of the action plan is carried out by a school meeting attended by the principal, the board of teachers, the school committee. Then followed up with meetings with parents and the community which was attended by muspika, head of UPT, parents and the community. Discuss plans for physical activities that support the implementation of a healthy school program involving the community and the stakeholders as accurately. These physical activities include environmental improvement and school roads, building healthy latrines, fixing healthy canteens, providing handwashing facilities, building sports facilities and holding trash bins. On this occasion also discussed the time and costs that support the smooth running of activities. In determining the timing of the implementation, there are differences of opinion but can be agreed to be adjusted to the opportunity of the community and the availability of materials to work on.

According to the researchers, all stages of the activity should be recommended in a complete administration and where they are easily searched. For example, in the management meeting activities there must be an invitation, attendance, minutes of the meeting and if necessary, there is a photo of the meeting activity at that time. Based on the facts in the field, documents that still include meeting attendance, minutes of meetings and photos of activities. Naum also has other activity documents that are incomplete or difficult to find. This needs to be a concern with all parties always to familiarize orderly administration in any activity.

2. Implementation Phase

The implementation or actuating of a healthy school program is an implementation of a plan that has been prepared. The term actuating, there are some experts who say the term "directing" is in line with Terry's opinion (in Usman Husaini (2014: 172), directing is actuating is getting all members in the group to want to archive the objective willingly in biting with managerial planning and organizing efforts, so actuating means action, because something won't happen without action.

In connection with the above theory, then after planning it is continued with the implementation of the activities of a healthy school program. What the principal does is coordinate with school committees, parents and the community and stakeholders related to the implementation of a healthy school program. Next is the division of tasks, the division of tasks is absolutely done so that there is no accumulation of work one point and emptiness at another point other than that so as not to cause overlap in the implementation of work. with the division of heavy work tasks, it becomes light because it is done together. Likewise in fixing facilities and infrastructures that support healthy school programs, it is necessary to develop tasks so that the activities to be carried out can be completed on time. The implementation is divided into two task areas, namely for activities that involve physical and environmental improvement of the school carried out by some teachers, students and assisted by parents, the community and participation from cross-sectoral agencies namely the police and the TNI, while those related to technical work are done by teacher of UKS coach and Puskesmas staff. In the activities of parents and school committees, the community and PKK and the Police and TNI are very proactive in supporting these activities.

Thus in the implementation process in accordance with existing theories, organizational activities take place. The movement of all components of the resource takes place, under the control of each coordinator of the established healthy school area and the principal as the person in charge of the healthy school activity program.

3. Evaluation Stages

Evaluation is part of the management system, namely planning, organization, implementation, monitoring, and evaluation. Without evaluation, it will not be known how the condition of the object of the evaluation in the design, implementation, and results. The process of evaluation in community empowerment is said to be a form of assessment of an activity that has been carried out. In line with that according to Arikunto and Abdul Jafar (2010: 297) "Program evaluation is an activity that is intended to find out how high the level of success of planned activities." Evaluation always seeks to determine the effectiveness and efficiency of implementation of a plan. In line with that according to Suchman in Arikunto and Abdul Jafar (2010: 1) view that, "evaluation as a process of determining the results achieved by several activities planned to support the achievement of goals."

Based on exposure to data and findings of research findings through interviews, observations and evaluation documents carried out by the principal of SDN No. 6 Siantan to find out the success of community empowerment in realizing a healthy school program seen from the goals achieved, the ongoing program and the involvement of parents, community and stakeholders in the activity. Evaluation is carried out after the completion of the activity by looking at the progress of the work carried out, if less work is found or still 
not done, repairs will be carried out or worked according to plan.

\section{CONCLUSION}

A. Conclusions

Based on the results of research on community empowerment management in realizing healthy schools in SDN No 6 Siantan, Siantan District, Mempawah Regency can be summarized as follows:

1. Planning Phase

The community empowerment planning process in referring to healthy schools has gone well and is adjusted at the beginning of the year the school principals, educators, and school committees by identifying the program need to be implemented integrated with the school program in accordance with the planned time.

2. Implementation Phase

The implementation of community empowerment has been going well, the Institute (SDN No. 6 Siantan) and the community have worked well in every activity, parental participation, community to be quite high in supporting the implementation of healthy school programs, this was shown by their enthusiasm in helping the school in fixing facilities that support healthy school programs.

3. Evaluation Phase

Evaluation of community empowerment activities in realizing healthy schools is carried out at the end of each activity. The evaluation was carried out by the principal, the head of the sub-district education office and the school committee. Evaluation of activities is measured by success if the planned goals have been achieved, the program runs smoothly, and there is involvement of parents and the community, and there is monitoring from relevant officials, namely from the Education office.

\section{B. Suggestions}

Based on the above achievement, for the sake of progress and achievement of empowerment, the researcher presents several suggestions and ideas that are expected to be useful to support the success of the implementation of community empowerment in schools:

1. For the head of SDN No. 6, Siantan should a) involve the community in disseminating school programs. Thus it is hoped that more people will know and support the program b) so that the schedule is made even though it is tentative in nature so that it becomes a reference in carrying out activities even though there will be changes later.

2. Schools, parents and keep maintaining work together to maintain and maintain the results of the work that has been produced together.

3. The need for sustainable empowerment so that healthy school programs can run continuously.

\section{REFERENCES}

Ali, Mubarak. (2010). Psikologi Remaja Perkembangan Peserta Didik. Jakarta: Bumi Aksara.

Andi Prastowo. (2011). Metode Penelitian Kualitatif dalam Perspektif Rancangan. Penelitian. Jogjakarta: ArRuzz Media.

Arikunto, S. and Jabar. (2004). Evaluasi Program Pendidikan. Jakarta: Bumi Aksara.

Handoko, T. Hani. (2003). Manajemen Personalia dan Sumber Daya Manusia. Yogyakarta: BPFEYogyakarta.

Husaini, Usman. (2013). Manajemen: Teori,Praktek dan Riset Pendidikan. .Jakarta: Bumi Aksara.

Soetomo. (2006). Strategi-Strategi Pembangunan Masyarakat. Yogyakarta: Pustaka Pelajar.

Sutisna, Oteng. (1989). Administrasi Pendidikan. Bandung: Angkasa. 